\title{
Halioglobus japonicus gen. nov., sp. nov. and Halioglobus pacificus sp. nov., members of the class Gammaproteobacteria isolated from seawater
}

Correspondence
Sanghwa Park
psh214@hotmail.com

\author{
Sanghwa Park, ${ }^{1}$ Susumu Yoshizawa, ${ }^{2}$ Kentaro Inomata, ${ }^{2}$ \\ Kazuhiro Kogure ${ }^{2}$ and Akira Yokota ${ }^{1}$ \\ ${ }^{1}$ Institute of Molecular and Cellular Biosciences, The University of Tokyo, 1-1-1 Yayoi, Bunkyo-Ku, \\ Tokyo 113-0032, Japan
${ }^{2}$ Atmosphere and Ocean Research Institute, The University of Tokyo, 5-1-5 Kashiwanoha, Kashiwa, Chiba 277-8564, Japan

\begin{abstract}
Two coccoid, non-motile bacteria were isolated from seawater in the north-western Pacific Ocean near Japan. The two strains, designated $\mathrm{S} 1-36^{\top}$ and $\mathrm{S} 1-72^{\top}$, were Gram-negative, obligately aerobic, heterotrophic and catalase-negative. They were able to reduce nitrate to nitrogen. Both strains required $\mathrm{NaCl}$ for growth, with optimum growth in $2 \% \mathrm{NaCl}$, and grew at $15-30{ }^{\circ} \mathrm{C}$, with optimum growth at $20-25^{\circ} \mathrm{C}$. Genomic DNA G $+\mathrm{C}$ contents of strains $\mathrm{S} 1-36^{\top}$ and $\mathrm{S} 1-72^{\top}$ were 59.6 and 59.4 mol\%, respectively. The predominant isoprenoid quinone was Q-8 and major cellular fatty acids were $\mathrm{C}_{16: 1} \omega 7 c, \mathrm{C}_{18: 1} \omega 7 c$ and $\mathrm{C}_{17: 1} \omega 8 c$. Analyses of $16 \mathrm{~S}$ rRNA gene sequences revealed that strains $S 1-36^{\top}$ and $S 1-72^{\top}$ were related to each other $(96.1 \%$ sequence similarity) and both strains showed $92.3-94.7 \%$ sequence similarity with members of the genus Haliea. On the basis of phenotypic and phylogenetic features, strains $\mathrm{S} 1-36^{\top}$ and $\mathrm{S} 1$ $72^{\top}$ should be classified as representatives of two novel species in a new genus, Halioglobus gen. nov., within the class Gammaproteobacteria. The names proposed are Halioglobus japonicus sp. nov., the type species of the genus, with $\mathrm{S} 1-36^{\top}\left(=\mathrm{NBRC} 107739^{\top}=\mathrm{KCTC} 23429^{\top}\right)$ as type strain, and Halioglobus pacificus sp. nov., with $\mathrm{S}_{1-72^{\top}}\left(=\mathrm{NBRC} 107742^{\top}=\mathrm{KCTC} 23430^{\top}\right)$ as type strain.
\end{abstract}

The genus Haliea in the family Alteromonadaceae was proposed by Urios et al. (2008b) and currently comprises Haliea salexigens (Urios et al., 2008b), Haliea rubra (Urios et al., 2009) and Haliea mediterranea (Lucena et al., 2010). These organisms belong to a branch of marine Gammaproteobacteria that corresponds to the so-called NOR5/ OM60 clade (Yan et al., 2009). This clade also includes Congregibacter litoralis, the first cultured representative of marine aerobic anoxygenic phototrophic Gammaproteobacteria. The NOR5 clade includes more than $50016 \mathrm{~S}$ rRNA gene sequences from public databases but, until recently, it has contained very few cultured and taxonomically characterized representatives.

Two aerobic bacteria, strains $\mathrm{S} 1-36^{\mathrm{T}}$ and $\mathrm{S} 1-72^{\mathrm{T}}$, isolated from seawater collected in the north-western Pacific Ocean

Abbreviations: $\mathrm{ML}$, maximum-likelihood; $\mathrm{NJ}$, neighbour-joining.

The GenBank/EMBL/DDBJ accession numbers for the $16 \mathrm{~S}$ rRNA gene sequences of strains $\mathrm{S} 1-36^{\top}$ and $\mathrm{S} 1-72^{\top}$ are $\mathrm{AB} 602427$ and AB602430, respectively.

Two supplementary figures and a supplementary table are available with the online version of this paper. were found to belong to the NOR5/OM60 clade within the class Gammaproteobacteria. A polyphasic taxonomic analysis of these isolates demonstrated that they represent two novel species in a new genus.

These aerobic bacteria were isolated from seawater samples collected from the north-western Pacific Ocean $\left(30^{\circ} 11^{\prime} \mathrm{N}\right.$ $145^{\circ} 05^{\prime} \mathrm{E}$; depth, $100 \mathrm{~m}$ ) during the $R / V$ Mirai [Japan Agency for Marine-Earth Science and Technology (JAMSTEC)] MR10-01 cruise on February 9, 2010. The seawater $(200 \mu \mathrm{l})$ sample was inoculated on $1 / 10$ strength ZoBell agar medium [0.5 g peptone, $0.1 \mathrm{~g}$ yeast extract, $15 \mathrm{~g}$ agar in $1180 \%$ aged natural seawater $(80 \%$ seawater $+20 \%$ water, aged for at least 6 months)] and incubated at $20{ }^{\circ} \mathrm{C}$ for 30 days. The isolated strains were maintained on marine agar 2216 (MA; Difco) at $25{ }^{\circ} \mathrm{C}$. The temperature $\left(5,10,15,20,25,30,37\right.$ and $\left.45^{\circ} \mathrm{C}\right)$ and $\mathrm{pH}(5-10)$ ranges for growth were determined on $\mathrm{MA}$. The $\mathrm{NaCl}$ concentration for growth was determined on MA containing 0, 1, 2, 3, 5, 8, 10 and $15 \%$ (w/v) $\mathrm{NaCl}$. Gram-staining was performed as described by Murray et al. (1994). Cell morphology and motility were observed using light microscopy (BX60; Olympus) and transmission electron 
microscopy. Growth under anaerobic conditions was determined after incubation for 4 weeks in an AnaeroPack (Mitsubishi Gas Chemical) on MA. Catalase activity was determined by bubble formation in a $3 \% \mathrm{H}_{2} \mathrm{O}_{2}$ solution. Oxidase activity was determined using cytochrome oxidase test paper (Nissui Pharmaceutical). API 20E, API 20NE, API 50CH and API ZYM strips (bioMérieux) were used to determine physiological and biochemical characteristics. All suspension media for the API test strips were supplemented with $2 \%(\mathrm{w} / \mathrm{v}) \mathrm{NaCl}$ solution (final concentration). API 20E, API 20NE and API 50CH tests were read after incubation for 5 days and API ZYM test strips were read after incubation for 2 days at $25{ }^{\circ} \mathrm{C}$. Respiratory quinone determination was carried out as described previously (Xie \& Yokota, 2003). The two novel bacterial strains were grown on MA for 3 weeks at $25{ }^{\circ} \mathrm{C}$ for analysis of fatty acid methyl esters. Fatty acid methyl esters were extracted and prepared according to standard protocols provided by the MIDI/Hewlett Packard Microbial Identification system Sherlock Version 4.0 TSBA 40 (Sasser, 1990). Polar lipids were extracted according to the procedures described by Minnikin et al. (1984). They were identified by twodimensional TLC followed by spraying with appropriate detection reagents (Minnikin et al., 1984; Komagata \& Suzuki, 1987). Phospholipids were detected with the Zinzadze reagent of Dittmer \& Lester (1964). Whole lipid profiles were detected by spraying with molybdatophosphoric acid (10 g molybdatophosphoric acid hydrate in $100 \mathrm{ml}$ ethanol) followed by heating at $120-160{ }^{\circ} \mathrm{C}$ (Worliczek et al., 2007). DNA was prepared according to the method of Marmur (1961) from cells grown on MA and the DNA $\mathrm{G}+\mathrm{C}$ content was determined by using the HPLC method of Mesbah et al. (1989). A fragment of approximately $1400 \mathrm{bp}$ from the $16 \mathrm{~S}$ rRNA gene was amplified from the extracted DNA by using bacterial universal primers specific to the $16 \mathrm{~S}$ rRNA gene: $27 \mathrm{~F}$ and 1492R (Lane, 1991; Weisburg et al., 1991). To ascertain the phylogenetic position of the novel isolates, the 16S rRNA gene sequences of strains $\mathrm{S} 1-36^{\mathrm{T}}$ and $\mathrm{S} 1-72^{\mathrm{T}}$ were compared with sequences obtained from GenBank (http:// www.ncbi.nlm.nih.gov). Multiple alignments of sequences were performed using CLUSTAL_X (version 1.83) (Thompson et al., 1997). Alignment gaps and ambiguous bases were not taken into consideration when the 1282 bases of $16 \mathrm{~S}$ rRNA gene nucleotides were compared. Aligned sequences were analysed using MEGA4 (Tamura et al., 2007). Evolutionary distances (Kimura, 1983), and clustering with the neighbour-joining (NJ: Saitou \& Nei, 1987) and maximumlikelihood (ML; Felsenstein, 1981) methods using PhyML program version 2.4.4 (Guindon \& Gascuel, 2003) were determined by using bootstrap values based on 1000 replications (Felsenstein, 1985). Similarities were calculated using the same software values.

Cells of strain $\mathrm{S} 1-36^{\mathrm{T}}$ and $\mathrm{S} 1-72^{\mathrm{T}}$ grown on MA at $25{ }^{\circ} \mathrm{C}$ for 3 weeks were coccoid-shaped, approximately 0.4 $0.6 \mu \mathrm{m}$ diameter. Flagella and spores were not observed microscopically (Fig. S1, available in IJSEM Online). No growth was observed under anaerobic conditions on MA. Growth occurred only under aerobic conditions between 15 and $30{ }^{\circ} \mathrm{C}$. Optimal temperature and $\mathrm{pH}$ ranges for growth were $20-25{ }^{\circ} \mathrm{C}$ and $\mathrm{pH} 7-8$, respectively. Both strains required $\mathrm{NaCl}$ for growth, but could not grow in $\mathrm{NaCl}$ concentrations above $8 \%$ (Table 1). The major cellular fatty acids of strains $\mathrm{S} 1-36^{\mathrm{T}}$ and $\mathrm{S} 1-72^{\mathrm{T}}$ were $\mathrm{C}_{16: 1} \omega 7 c$ (24.6 and $25.4 \%$, respectively), $\mathrm{C}_{18: 1} \omega 7 c$ (18.9 and $16.6 \%)$ and $\mathrm{C}_{17: 1} \omega 8 \mathrm{c}(9.0$ and $11.1 \%$ ) (Table S1).

The polar lipids of strain S1-36 ${ }^{\mathrm{T}}$ comprised phosphatidylglycerol, diphosphatidylglycerol, phosphatidylethanolamine and an unidentified phospholipid, whereas those of strain S1-72 ${ }^{\mathrm{T}}$ were phosphatidylglycerol, two diphosphatidylglycerols and an unidentified phospholipid (Fig. S2).

Physiological and biochemical characteristics of strains S1$36^{\mathrm{T}}$ and $\mathrm{S} 1-72^{\mathrm{T}}$ were compared with those of members of related genera, i.e. Haliea (Urios et al., 2008b), Congregibacter (Spring et al., 2009), Dasania (Lee et al., 2007), 'Oceanicoccus' (Park et al., 2011), Spongiibacter (Graeber et al., 2008), Melitea (Urios et al., 2008a) and Zhongshania (Li et al., 2011), in the class Gammaproteobacteria (Table 1).

Almost complete 16S rRNA gene sequences for strain S1$36^{\mathrm{T}}$ and $\mathrm{S} 1-72^{\mathrm{T}}$ were determined and a BLAST search in the GenBank showed that the strains belonged to the class Gammaproteobacteria. Strains $\mathrm{S} 1-36^{\mathrm{T}}$ and $\mathrm{S} 1-72^{\mathrm{T}}$ showed $96.1 \%$ sequence similarity to each other and high $16 \mathrm{~S}$ rRNA gene sequence similarities to $H$. salexigens $3 \mathrm{X} / \mathrm{A} 02 /$ $235^{\mathrm{T}}$ (93.3 and $94.3 \%$, respectively), $H$. mediterranea $7 \mathrm{SM} 29^{\mathrm{T}}(92.7$ and $94.7 \%$, respectively) and $H$. rubra CM41_15a ${ }^{\mathrm{T}}$ (92.7 and $94.0 \%$, respectively). Phylogenetic trees obtained by the NJ (Fig. 1) and ML methods revealed clear affiliations of the novel isolates $\mathrm{S} 1-36^{\mathrm{T}}$ and $\mathrm{S} 1-72^{\mathrm{T}}$ to the cluster comprising $H$. salexigens $3 \mathrm{X} / \mathrm{A} 02 / 235^{\mathrm{T}}, H$. mediterranea $7 \mathrm{SM} 29^{\mathrm{T}}$, H. rubra CM41_15a $\mathrm{a}^{\mathrm{T}}$, C. litoralis $\mathrm{KT} 71^{\mathrm{T}}$ and six uncultured clones.

In summary, their coccoid shape, catalase-negative activity, esterase activity, and ability to utilize arabinose, ribose and fructose distinguish strains $\mathrm{S} 1-36^{\mathrm{T}}$ and $\mathrm{S} 1-72^{\mathrm{T}}$ from members of the most closely related genus Haliea. Also, strain $\mathrm{S} 1-36^{\mathrm{T}}$ differed from $\mathrm{S} 1-72^{\mathrm{T}}$ in $N$-acetyl- $\beta$-glucosaminidase and naphthol-AS-BI-phosphohydrolase activities, hydrolysis of aesculin, utilization of glycerol, maltose and trehalose, and polar lipid profiles.

Differential physiological and chemotaxonomic properties of strains $\mathrm{S} 1-36^{\mathrm{T}}$ and $\mathrm{S} 1-72^{\mathrm{T}}$ and related genera are shown in Table 1. The data presented show that strains $\mathrm{S} 1-36^{\mathrm{T}}$ and $\mathrm{S} 1-72^{\mathrm{T}}$ are sufficiently different from related genera and that they represent two novel species, Halioglobus japonicus gen. nov., sp. nov. and Halioglobus pacificus sp. nov., in a new genus in the class Gammaproteobacteria.

\section{Description of Halioglobus gen. nov.}

Halioglobus (Ha.li.o.glo'bus. Gr. adj. halios belonging to the sea or marine; L. masc. n. globus a ball, sphere, globe; N.L. masc. n. Halioglobus a marine coccus). 
Table 1. Differential characteristics of strains $\mathrm{S} 1-36^{\top}$ and $\mathrm{S} 1-72^{\top}$ and related genera in the class Gammaproteobacteria

Taxa: 1, S1-36' ; 2, S1-72 ${ }^{\mathrm{T}}$; 3, Haliea (Urios et al., 2008b, 2009; Lucena et al., 2010); 4, Congregibacter (Spring et al., 2009); 5, Dasania (Lee et al., 2007); 6, 'Oceanicoccus' (Park et al., 2011); 7, Spongiibacter (Graeber et al., 2008; Hwang \& Cho, 2009); 8, Melitea (Urios et al., 2008a); 9, Zhongshania (Li et al., 2011). -, Negative or none; v, variable; ND, no data available.

\begin{tabular}{|c|c|c|c|c|c|c|c|c|c|}
\hline Characteristic & 1 & 2 & 3 & 4 & 5 & 6 & 7 & 8 & 9 \\
\hline Shape & Coccus & Coccus & Rod & Pleomorphic & Irregular rod & $\begin{array}{l}\text { Coccus/ } \\
\text { amorphous }\end{array}$ & Rod & Rod & Rod \\
\hline Flagellation & - & - & $\mathrm{V}$ & + & + & + & + & + & + \\
\hline \multicolumn{10}{|l|}{ Growth temperature $\left({ }^{\circ} \mathrm{C}\right)$} \\
\hline Range & $10-30$ & $10-30$ & $10-44$ & $9-33$ & $4-30$ & $10-30$ & $10-40$ & $15-37$ & $4-35$ \\
\hline Optimum & $20-25$ & $20-25$ & $25-30$ & 28 & $17-22$ & $15-20$ & $20-35$ & 30 & 30 \\
\hline $\mathrm{NaCl}$ tolerance $(\%)$ & $1-4$ & $1-5$ & $0.4-15$ & $1-7$ & $1-9$ & $1-5$ & $1-9$ & $0.7-7$ & $0-9$ \\
\hline Catalase & - & - & + & + & + & - & + & + & + \\
\hline Esterase & + & + & - & ND & - & + & + & - & ND \\
\hline$N$-Acetyl- $\beta$-glucosaminidase & - & + & $\mathrm{v}$ & $\mathrm{ND}$ & - & - & $\mathrm{V}$ & - & ND \\
\hline \multicolumn{10}{|l|}{ Utilization of: } \\
\hline Arabinose & - & - & - & $\mathrm{ND}$ & - & + & $\mathrm{v}$ & - & - \\
\hline Glucose & + & + & $\mathrm{v}$ & - & - & + & ND & + & - \\
\hline Ribose & + & + & - & ND & - & + & ND & ND & ND \\
\hline Fructose & + & + & - & - & - & - & - & + & ND \\
\hline Maltose & + & - & $\mathrm{v}$ & ND & - & - & ND & + & - \\
\hline Polar lipids* & PG, DPG, PE, PL & $\begin{array}{c}\text { PG, } 2 \text { DPG } \\
\text { PL }\end{array}$ & $\begin{array}{c}\text { PG, DPG, PE } \\
\text { AL, GL }\end{array}$ & PC, PE, PL & ND & $\mathrm{ND}$ & ND & ND & ND \\
\hline DNA G $+\mathrm{C}$ content $(\mathrm{mol} \%)$ & 59.6 & 59.4 & $61.4-64.8$ & 57.8 & 37 & 49.8 & $57.7-69.1$ & 57 & $51.5-51.8$ \\
\hline
\end{tabular}

${ }^{*}$ DPG, Diphosphatidylglycerol; PE, phosphatidylethanolamine; PG, phosphatidylglycerol; AL, unidentified aminolipid; GL, atypical glycolipid; PL, unidentified phospholipid. 


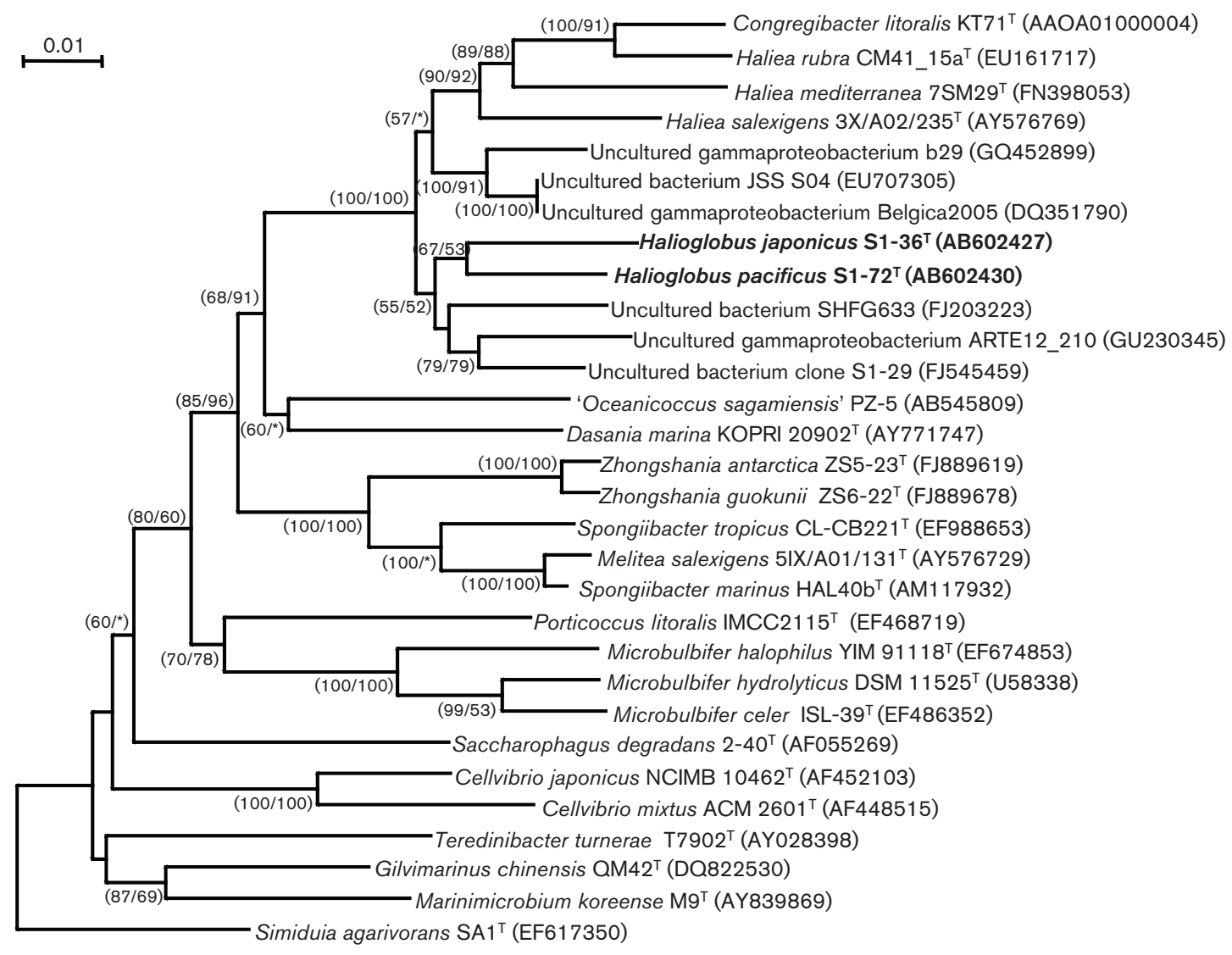

Fig. 1. NJ phylogenetic tree based on the $16 \mathrm{~S}$ rRNA gene sequences showing the position of strains $\mathrm{S} 1-36^{\top}$ and $\mathrm{S} 1-72^{\top}$, among the currently known and related species of the family Alteromonadaceae. Numbers at nodes are bootstrap percentages derived from 1000 replications (NJ/ML). The sequence of Simiduia agarivorans SA1 ${ }^{\top}$ (EF617350) was used as an outgroup. Bar, 0.01 substitutions per nucleotide position. Asterisks indicate nodes recovered with nodes with bootstrap values $<50 \%$ in the $\mathrm{ML}$ tree.

Cells are coccoid shaped, non-motile, Gram-negative and obligately aerobic. Catalase-negative and oxidase-positive. $\mathrm{NaCl}$ is need for growth. Nitrate is reduced to $\mathrm{N}_{2}$. The respiratory quinone is Q-8. Predominant cellular fatty acids are $\mathrm{C}_{16: 1} \omega 7 c, \mathrm{C}_{18: 1} \omega 7 c$ and $\mathrm{C}_{17: 1} \omega 8 c$. The polar lipids present are phosphatidylglycerol, diphosphatidylglycerol and an undefined phospholipid. The type species is Halioglobus japonicus.

\section{Description of Halioglobus japonicus sp. nov.}

Halioglobus japonicus (ja.po'ni.cus. N.L. masc. adj. japonicus pertaining to Japan, from where the isolate originated).

Exhibits the following properties in addition to those given in the genus description. Cells are $0.3-0.5 \mu \mathrm{m}$ in diameter. Temperature range for growth is $15-30{ }^{\circ} \mathrm{C}$. Optimal temperature for growth is $20-25{ }^{\circ} \mathrm{C}$. No growth occurs above $37^{\circ} \mathrm{C}$. $\mathrm{pH}$ range for growth is 6.0-9.0; optimum is $\mathrm{pH}$ 7.0-8.0. $\mathrm{NaCl}$ is required for growth. Optimum $\mathrm{NaCl}$ concentration for growth is $2 \%$; tolerates up to $4 \%(\mathrm{w} / \mathrm{v})$ $\mathrm{NaCl}$. Catalase-negative but oxidase-positive. Production of acetoin and reduction of nitrate to $\mathrm{N}_{2}$ are observed. Gelatin and aesculin are hydrolysed but agar and starch are not. Alkaline phosphatase, esterase (C4), esterase lipase (C8), lipase (C14), valine arylamidase, cystine arylamidase, trypsin, $\alpha$-chymotrypsin, acid phosphatase, naphthol-ASBI-phosphohydrolase and $N$-acetyl- $\beta$-glucosaminidase are positive but leucine arylamidase, $\beta$-glucosidase $\alpha$-galactosidase, $\beta$-galactosidase, $\alpha$-glucosidase, $\beta$-glucuronidase, $\alpha$-mannosidase and $\alpha$-fucosidase are negative. Acid is produced from ribose, glucose, fructose, aesculin, maltose, sucrose, trehalose and glycogen but not from glycerol, galactose, $\mathrm{N}$-acetylglucosamine, melibiose, mannose, turanose, D-lyxose, 5-ketogluconate, D-arabinose, L-arabinose, D-tagatose, starch, xylitol, D-xylose, L-xylose, methyl $\beta$-Dxylopyranoside, rhamnose, methyl $\alpha$-D-mannnopyranoside, methyl $\alpha$-D-glucopyranoside, amygdalin, arbutin, salicin, cellobiose, lactose, melezitose, inulin, raffinose, gentiobiose, D-fucose, L-fucose, erythritol, adonitol, sorbose, dulcitol, inositol, mannitol, sorbitol, D-arabitol, L-arabitol, gluconate or 2-ketogluconate. Major cellular fatty acids $(\geqslant 5 \%)$ are $\mathrm{C}_{16: 1} \omega 7 c, \mathrm{C}_{18: 1} \omega 7 c, \mathrm{C}_{17: 1} \omega 8 c, \mathrm{C}_{11: 0}, \mathrm{C}_{10: 0}$ and $\mathrm{C}_{17: 0}$. 
The type strain, $\mathrm{S} 1-36^{\mathrm{T}}\left(=\mathrm{NBRC} 107739^{\mathrm{T}}=\mathrm{KCTC} 23429^{\mathrm{T}}\right)$, was isolated from the north-western Pacific Ocean near Japan. The DNA G + C content of the type strain is $59.6 \mathrm{~mol} \%$.

\section{Description of Halioglobus pacificus sp. nov.}

Halioglobus pacificus (pa.ci'fi.cus. L. masc. adj. pacificus peaceful, pertaining to the Pacific Ocean).

Exhibits the following properties in addition to those given in the genus description. Cells are $0.3-0.5 \mu \mathrm{m}$ in diameter. Temperature range for growth is $15-30{ }^{\circ} \mathrm{C}$. Optimal temperature for growth is $20-25{ }^{\circ} \mathrm{C}$. No growth occurs above $37^{\circ} \mathrm{C}$. $\mathrm{pH}$ range for growth is $6.0-10.0$; optimum is $\mathrm{pH} 7.0-8.0 . \mathrm{NaCl}$ is required for growth. Optimum $\mathrm{NaCl}$ concentration is $2 \%$; tolerates up to $5 \%(\mathrm{w} / \mathrm{v})$ $\mathrm{NaCl}$. Catalase-negative but oxidase-positive. Production of acetoin and reduction of nitrate to $\mathrm{N}_{2}$ are observed. Gelatin is hydrolysed but agar, starch, aesculin are not hydrolysed. Alkaline phosphatase, esterase (C4), esterase lipase (C8), lipase (C14), valine arylamidase, cystine arylamidase, trypsin, $\alpha$-chymotrypsin and acid phosphatase are positive but leucine arylamidase, $\beta$-glucosidase, $\alpha$ galactosidase, $\beta$-galactosidase, $\alpha$-glucosidase, $\beta$-glucuronidase, $\alpha$-mannosidase, naphthol-AS-BI-phosphohydrolase, $N$-acetyl- $\beta$-glucosaminidase and $\alpha$-fucosidase are negative. Acid is produced from glycerol, ribose, glucose, fructose, sucrose, arbutin and glycogen but not from galactose, $\mathrm{N}$ acetylglucosamine, melibiose, mannose, turanose, 5-ketogluconate, D-arabinose, maltose, D-tagatose, D-xylose, Larabinose, L-xylose, methyl $\beta$-D-xylopyranoside, rhamnose, methyl $\alpha$-D-mannnopyranoside, methyl $\alpha$-D-glucopyranoside, amygdalin, arbutin, salicin, cellobiose, lactose, melezitose, inulin, raffinose, trehalose, gentiobiose, D-fucose, Lfucose, erythritol, adonitol, sorbose, dulcitol, inositol, mannitol, sorbitol, starch, aesculin, xylitol, D-arabitol, Larabitol, gluconate or 2-ketogluconate. Major cellular fatty acids $(\geqslant 5 \%)$ are $\mathrm{C}_{16: 1} \omega 7 c, \mathrm{C}_{18: 1} \omega 7 c, \mathrm{C}_{17: 1} \omega 8 c$ and $\mathrm{C}_{11: 0}$.

The type strain, $\mathrm{S} 1-72^{\mathrm{T}}\left(=\mathrm{NBRC} 107742^{\mathrm{T}}=\mathrm{KCTC} 23430^{\mathrm{T}}\right)$, was isolated from the north-western Pacific Ocean near Japan. The DNA G + C content of the type strain is $59.4 \mathrm{~mol} \%$.

\section{Acknowledgements}

We are grateful to the officers and crew of $R / V$ Mirai [Atmosphere and Ocean Research Institute, The University of Tokyo, and Japan Agency for Marine-Earth Science and Technology (JAMSTEC)] for their assistance and support in sample collection.

\section{References}

Dittmer, J. C. \& Lester, R. L. (1964). A simple, specific spray for the detection of phospholipids on thin-layer chromatograms. J Lipid Res 15, 126-127.

Felsenstein, J. (1981). Evolutionary trees from DNA sequences: a maximum likelihood approach. J Mol Evol 17, 368-376.

Felsenstein, J. (1985). Confidence limits on phylogenies: an approach using the bootstrap. Evolution 39, 783-791.
Graeber, I., Kaesler, I., Borchert, M. S., Dieckmann, R., Pape, T., Lurz, R., Nielsen, P., von Döhren, H., Michaelis, W. \& Szewzyk, U. (2008). Spongiibacter marinus gen. nov., sp. nov., a halophilic marine bacterium isolated from the boreal sponge Haliclona sp. 1. Int J Syst Evol Microbiol 58, 585-590.

Guindon, S. \& Gascuel, O. (2003). A simple, fast, and accurate algorithm to estimate large phylogenies by maximum likelihood. Syst Biol 52, 696-704.

Hwang, C. Y. \& Cho, B. C. (2009). Spongiibacter tropicus sp. nov., isolated from a Synechococcus culture. Int J Syst Evol Microbiol 59, 2176-2179.

Kimura, M. (1983). The Neutral Theory of Molecular Evolution. Cambridge: Cambridge University Press.

Komagata, K. \& Suzuki, K. (1987). Lipid and cell-wall analysis in bacterial systematics. Methods Microbiol 19, 161-207.

Lane, D. J. (1991). 16S/23S rRNA sequencing. In Nucleic Acid Techniques in Bacterial Systematics, pp. 115-147. Edited by E. Stackebrandt \& M. Goodfellow. New York: John Wiley and Sons.

Lee, Y. K., Hong, S. G., Cho, H. H., Cho, K. H. \& Lee, H. K. (2007). Dasania marina gen. nov., sp. nov., of the order Pseudomonadales, isolated from Arctic marine sediment. J Microbiol 45, 505-509.

Li, H., Zhang, S., Chen, C., Zhang, Y., Gao, Z., Yu, Y., Chen, X., Chen, B. \& Zhang, Y. (2011). Zhongshania antarctica gen. nov., sp. nov. and Zhongshania guokunii sp. nov., new members of the Gammaproteobacteria isolated from coastal attached (fast) ice and surface seawater of the Antarctic, respectively. Int J Syst Evol Microbiol 61, 2052-2057.

Lucena, T., Pascual, J., Garay, E., Arahal, D. R., Macián, M. C. \& Pujalte, M. J. (2010). Haliea mediterranea sp. nov., a marine gammaproteobacterium. Int J Syst Evol Microbiol 60, 1844-1848.

Marmur, J. (1961). A procedure for the isolation of deoxyribonucleic acid from micro-organisms. J Mol Biol 3, 208-218.

Mesbah, M., Premachandran, U. \& Whitman, W. B. (1989). Precise measurement of the $\mathrm{G}+\mathrm{C}$ content of deoxyribonucleic acid by highperformance liquid chromatography. Int J Syst Bacteriol 39, 159-167.

Minnikin, D. E., O’Donnell, A. G., Goodfellow, M., Alderson, G., Athalye, M., Schaal, A. \& Parlett, J. H. (1984). An integrated procedure for the extraction of bacterial isoprenoid quinones and polar lipids. J Microbiol Methods 2, 233-241.

Murray, R. G. E., Doetsch, R. N. \& Robinow, F. (1994). Determinative and cytological light microscopy. In Methods for General and Molecular Bacteriology, pp. 21-41. Edited by P. Gerhardt, R. G. E. Murray, W. A. Wood \& N. R. Krieg. Washington, DC: American Society for Microbiology.

Park, S., Yoshizawa, S., Kogure, K. \& Yokota, A. (2011). Oceanicoccus sagamiensis gen. nov., sp. nov., a gammaproteobacterium isolated from sea water of Sagami Bay in Japan. J Microbiol 49, 233-237.

Saitou, N. \& Nei, M. (1987). The neighbor-joining method: a new method for reconstructing phylogenetic trees. Mol Biol Evol 4, 406425.

Sasser, M. (1990). Identification of bacteria by gas chromatography of cellular fatty acids, MIDI Technical Note 101. Newark, DE: MIDI Inc.

Spring, S., Lünsdorf, H., Fuchs, B. M. \& Tindall, B. J. (2009). The photosynthetic apparatus and its regulation in the aerobic gammaproteobacterium Congregibacter litoralis gen. nov., sp. nov. PLoS ONE 4, e4866.

Tamura, K., Dudley, J., Nei, M. \& Kumar, S. (2007). MEGA4: molecular evolutionary genetics analysis (MEGA) software version 4.0. Mol Biol Evol 24, 1596-1599.

Thompson, J. D., Gibson, T. J., Plewniak, F., Jeanmougin, F. \& Higgins, D. G. (1997). The CLUSTAL_X windows interface: flexible 
strategies for multiple sequence alignment aided by quality analysis tools. Nucleic Acids Res 25, 4876-4882.

Urios, L., Agogué, H., Intertaglia, L., Lesongeur, F. \& Lebaron, P. (2008a). Melitea salexigens gen. nov., sp. nov., a gammaproteobacterium from the Mediterranean Sea. Int J Syst Evol Microbiol 58, 24792483.

Urios, L., Intertaglia, L., Lesongeur, F. \& Lebaron, P. (2008b). Haliea salexigens gen. nov., sp. nov., a member of the Gammaproteobacteria from the Mediterranean Sea. Int J Syst Evol Microbiol 58, 1233-1237.

Urios, L., Intertaglia, L., Lesongeur, F. \& Lebaron, P. (2009). Haliea rubra sp. nov., a member of the Gammaproteobacteria from the Mediterranean Sea. Int J Syst Evol Microbiol 59, 1188-1192.
Weisburg, W. G., Barns, S. M., Pelletier, D. A. \& Lane, D. J. (1991). 16 S ribosomal DNA amplification for phylogenetic study. J Bacteriol 173, 697-703.

Worliczek, H. L., Kämpfer, P., Rosengarten, R., Tindall, B. J. \& Busse, H. J. (2007). Polar lipid and fatty acid profiles - re-vitalizing old approaches as a modern tool for the classification of mycoplasmas? Syst Appl Microbiol 30, 355-370.

Xie, C. H. \& Yokota, A. (2003). Phylogenetic analyses of Lampropedia hyalina based on the 16S rRNA gene sequence. J Gen Appl Microbiol 49, 345-349.

Yan, S., Fuchs, B. M., Lenk, S., Harder, J., Wulf, J., Jiao, N.-Z. \& Amann, R. (2009). Biogeography and phylogeny of the NOR5/OM60 clade of Gammaproteobacteria. Syst Appl Microbiol 32, 124-139. 